\title{
Subcutaneous Emphysema: An Unusual Complication Following External Dacryocystorhinostomy
}

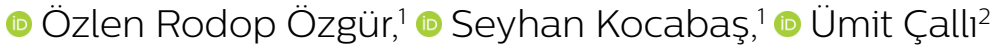

\author{
'Department of Ophthalmology, \\ University of Health Sciences, \\ Kartal Dr. Lütfi Kırdar Training and \\ Research Hospital, İstanbul, Turkey \\ ${ }^{2}$ Department of Ophthalmology, \\ University of Health Sciences, \\ Ümraniye Training and Research \\ Hospital, İstanbul, Turkey \\ Submitted: 11.02.2018 \\ Accepted: 03.01.2019
}

Correspondence: Seyhan Kocabaş, SBÜ Kartal Dr. Lütfi Kırdar Eğitim ve Araştırma Hastanesi, Göz Hastalıkları Kliniği, İstanbul, Turkey

E-mail: seyhankcbs@gmail.com

Keywords: Complications;
dacryocystorhinostomy;
emphysema.
(6) $\mathbf{0}$.
Attribution-Noncommercial 4.0 International License.

\begin{abstract}
A periorbital subcutaneous emphysema that developed after a successful external dacryocystorhinostomy (DSR) has been presented. The patient gave a history of sudden swelling of bilateral eyelids after a forceful sneeze and blowing of the nose. Physical examination showed periorbital edema and hyperemia; palpation of the swollen region revealed crepitation. These signs and symptoms suggested subcutaneous emphysema. Subcutaneous or orbital emphysema occurring after DSR is a rare complication. Pure subcutaneuos emphysema recovers spontaneously in a short period.
\end{abstract}

\section{INTRODUCTION}

Orbital emphysema is characterized by the presence of abnormal air in the loose soft tissue around the orbits. ${ }^{[l]}$ It is very rarely seen without any evidence of trauma. ${ }^{[2]}$ It is mostly a benign, temporary, and self-limiting event and rarely results in loss of ischemic vision. ${ }^{[3]}$

Here we present a case of subcutaneous emphysema developing around the eyes after a successful external dacryocystorhinostomy (DSR).

\section{CASE REPORT}

A 70-year-old male patient was admitted to the emergency department with the complaint of sudden swelling of bilateral eyelids and redness in the right eye 2 days after he had undergone DSR. Another antibiotic treatment was added to the existing systemic and topical antibiotic therapy by the physician at the emergency room, and the patient was referred to the oculoplasty clinic for the control visit the next day. His medical history was unremarkbale. Preoperative ear-nose-throat examination did not reveal any pathology. He gave a history of sudden swelling of bilateral eyelids after a forceful sneeze and blowing of the nose. Physical examination revealed severe swelling and hyperemia around his eyes (Fig. la). Crepitation on palpation was observed in the swollen region. The eye movements were natural, and the visual accuracy was the same as that before the surgery. No pathology was detected on anterior and posterior segment examination.

These findings led to a diagnosis of periorbital emphysema; systemic and topical routine treatment followed by systemic antihistamine treatment was prescribed for the patient. An examination conducted during the control visit after I week revealed a complete regression of the swelling and hyperemia of the eyelids and absence of the crepitation (Fig. Ib). The patient did not have any com- 

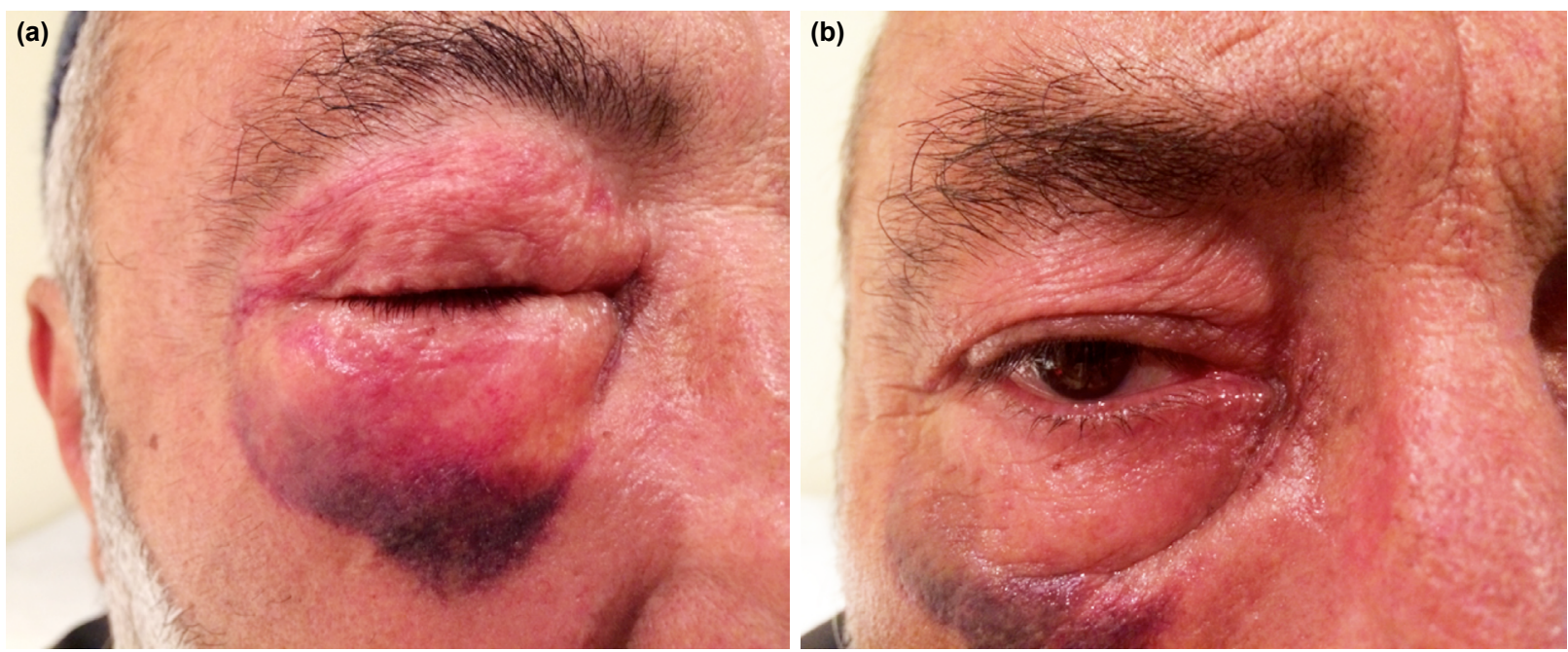

Figure 1. (a) The appearance of the affected area on the $4^{\text {th }}$ postoperative day in the patient who had developed periorbital emphysema on $2^{\text {nd }}$ postoperative day. (b) Remarkable regression of the patient's periorbital emphysema was observed on $10^{\text {th }}$ postoperative day.

plaints of watering from the eyes, and irrigation of his nasolacrimal canal revealed a patent canal.

\section{DISCUSSION}

Orbital emphysema is often caused by the fracture of the orbital wall, allowing the air in the paranasal sinuses to pass through to the orbit. Orbital, subconjunctival subcutaneous, and subcutaneous emphysemas occur after the air in the orbital wall and nasal cavity enters between the loose tissues in the orbit. ${ }^{[4,5]}$

Cases of orbital emphysema are rarely reported after lacrimal duct surgery. After anesthesia induction, the Valsalva maneuver, such as spasm of the larynx, sneezing and blowing one's nose, forces the air in the nasal cavity to pass from the DSR opening to the orbital and subcutaneous tissues, creating a positive high pressure. ${ }^{[6]}$ Ajit et al. ${ }^{[7]}$ have reported orbital emphysema after balloon dacryoplasty. Ghosheh and Kathuria ${ }^{[8]}$ have reported the case of a patient who developed periorbital crepitration after undergoing DSR. In our patient, subcutaneous emphysema with periorbital crepitation developed on the second day after a successful DSR after a strong blowing of the nose.

In most patients, orbital emphysema usually resolves spontaneously within 2-3 weeks without affecting eye functions. During this period, one should remain alert against the development of compressive optic neuropathy and exposure keratopathy because vision-threatening sequelae have been reported..$^{[5,9]}$

There is no standard approach algorithm for orbital emphysema. However, Hunts et al. ${ }^{[1,2]}$ have proposed a grading protocol for the diagnosis and treatment of orbital emphysema. Careful follow-up and prevention of strong blowing of one's nose is the only treatment required for orbital emphysema. ${ }^{[0,1]]}$ Besides, prophylactic antibiotics, decongestants, steroids may be given. In our patient, in addition to these treatments, an antihistaminic was started to prevent intranasal irritation. Close follow-up showed that periorbital emphysema resolved spontaneously within I week. However, in cases where vision is threatened, it may be necessary to refer to surgical methods such as lateral canthotomy, needle aspiration, orbital decompression or bone decompression. ${ }^{[12,13]}$

Subcutaneous emphysema and orbital emphysema after DSR are rare complications. Patients should be advised to avoid actions that may cause sudden pressure changes such as strong coughing, sneezing, and straining. Subcutaneous emphysema spontaneously regresses; however patient follow-up is required.

Informed Consent

Written informed consent was obtained from the patient for the publication of the case report and the accompanying images.

Peer-review

Internally peer-reviewed.

Authorship Contributions

Concept: Ö.R.Ö., S.K., Ü.Ç.; Design: Ö.R.Ö., S.K., Ü.Ç.; Data collection \&/or processing: Ü.Ç.; Analysis and/or interpretation: Ö.R.Ö.; Literature search: Ö.R.Ö.; Writing: S.K.; Critical review: Ü.Ç.

Conflict of Interest

None declared.

\section{REFERENCES}

1. Sever M, Büyüky1lmaz. Orbital Emphysema due to Nose Blowing. Turk J Med Sci 2009;39:143-5.

2. Hunts JH, Patrinely JR, Holds JB, Anderson RL. Orbital emphysema. Staging and acute management. Ophthalmology 1994;101:960-6.

3. García-Medina JJ, García-Medina M, Pinazo-Durán MD. Severe orbitopalpebral emphysema after nose blowing requiring emergency decompression. Eur J Ophthalmol 2006;16:339-42. [CrossRef]

4. Yuksel M, Yuksel KZ, Ozdemir G, Ugur T. Bilateral orbital emphy- 
sema and pneumocephalus as a result of accidental compressed air exposure. Emerg Radiol 2007;13:195-8. [CrossRef]

5. Ababneh $\mathrm{OH}$. Orbital, subconjunctival, and subcutaneous emphysema after an orbital floor fracture. Clin Ophthalmol 2013;7:1077-9.

6. Yakopson VS, Flanagan JC, Ahn D, Luo BP. Dacryocystorhinostomy: History, evolution and future directions. Saudi J Ophthalmol 2011;25:37-49. [CrossRef]

7. Ajit R, Inkster C, Tuck J, Mortzos P. Orbital emphysema: an unusual complication of balloon dacryocystoplasty. $\mathrm{Br} \mathrm{J}$ Radiol 2004;77:1057-8. [CrossRef]

8. Ghosheh FR, Kathuria SS. Massive subcutaneous emphysema mimicking necrotizing fasciitis after dacryocystorhinostomy. Ophthalmic Plast Reconstr Surg 2005;21:389-91. [CrossRef]
9. Caesar R, Gajus M, Davies R. Compressed air injury of the orbit in the absence of external trauma. Eye (Lond) 2003;17:661-2. [CrossRef]

10. Benharbit M, Karim A, Lazreq M, Mohcine Z. Emergency treatment of post-traumatic orbital emphysema: a case report. [Article in French]. J Fr Ophtalmol 2003;26:957-9.

11. Gonzalez F, Cal V, Elhendi W. Orbital emphysema after sneezing. Ophthalmic Plast Reconstr Surg 2005;21:309-11. [CrossRef]

12. Weber D, Shaw S, Winslow J. Traumatic eye swelling. Subconjunctival and orbital emphysema with orbital floor fracture. Ann Emerg Med 2009;54:635-42. [CrossRef]

13. Chak G, Joseph JM, Tao JP. Needle decompression of acute orbital emphysema: case report with video. Br J Ophthalmol 2012;96:13467. [CrossRef]

\section{Ciltalti Amfizemi: Eksternal Dakriyosistorinostomi Sonrasi Gelişen Nadir Bir Komplikasyon}

Başarılı bir eksternal dakriyosistorinostomi (DSR) cerrahisi sonrası göz çevresinde gelişen cilt altı amfizemi olgusu sunulmuştur. Öyküsünde kuvvetli hapşırma ve sümkürme sonrası göz kapaklarının ani şiştiğini ifade eden hastanın muayenesinde göz çevresi ileri derecede şiş ve hiperemikti. Palpasyonla krepitasyon mevcuttu. Bu bulgular ile cilt altı amfizemi tanısı konuldu. DSR sonrası cilt altı amfizemi ve hatta orbital amfizem nadir de olsa gelişebilecek bir komplikasyondur. Sadece cilt altı amfizemi olguları takip ile kendiliğinden kısa sürede gerilemektir.

Anahtar Sözcükler: Amfizem; dakriyosistorinostomi; komplikasyon. 